\title{
DOES THE FERTILIZATION AND REPRODUCTION SUCCESS IN ISO 5/7 LABOR HAVE A DIFFERENCE WHEN COMPARED TO A CONVENTIONAL LABORATORY?
}

\author{
Érica Eugênio Lourenço Gontijo ${ }^{1 *}$, Marcos Gontijo da Silva², Ana Maria de Castro ${ }^{3}$, \\ Hanstter Hallison Alves Rezende ${ }^{4}$, Mário Silva Approbato ${ }^{3}$ \\ ${ }^{1}$ University of Gurupi, Gurupi, Tocantins Brazil \\ ${ }^{2}$ Federal University of Tocantins, Araguaína, Tocantins, Brazil \\ ${ }^{3}$ Federal University of Goiás, Goiânia, Goiás, Brazil \\ ${ }^{4}$ Federal University of Jataí, Jataí, Goiás, Brazil
}

\begin{abstract}
OBJECTIVE: To evaluate the tax of embryo's development, embryo quality, chemical pregnancy and microbiological evaluation of the means of embryos' cultivation from patients attended at the Human Reproduction Laboratory of the conventional laboratory and after the adjustment of RDC $n^{\circ} 23$ de 2011, when it started to be classified as ISO 5/7 laboratory in 2013 and 2014. METHODOLOGY: This control case study was developed at the LabRep/HC/UFG, located in Goiânia, Goiás, Brazil. It uses indirect observation as research technique in order to analyze the records of women attended at the laboratory. From the total of women researched, 87 of them were from the conventional laboratory and 191 were from the ISO 5/7 laboratory. The variables analyzed were: embryo's development, $\beta$ hCG result, embryo quality and the assessed microbiological contamination of the means of embryos' cultivation. The data was inserted in the Epi-Info 33.2 program and it was analyzed in Bioestat 2.3. The groups were compared by odds ratio (OR) and chi-square with $p<5 \%$. RESULTS: In ISO 5/7 laboratory, there was $74.1 \%$ of success in the embryo's development while in the conventional laboratory, there was $67.8 \%$ (OR: 1,30; IC: 0,47-3,61; $\chi^{2}: 0,24 ;$ p: 0.81). Moreover, in ISO 5/7 laboratory, 96.6\% of the generated embryos were A or B, whereas $90.4 \%$ in the conventional laboratory (OR: 0,8906 ; IC: $0,27-2,89 ; \chi^{2}: 0,037 ; p: 0,85$ ). The pregnancy success in ISO 5/7 laboratory was $22.8 \%$ and $36.2 \%$ in the conventional laboratory (OR: 1,92; IC: $0,81-4,52 ; \chi^{2}: 2,24 ;$ p: 0,13 ). CONCLUSION: There was not a statistic difference between both laboratories.
\end{abstract}

Keywords: laboratory quality in FIV, embryo quality, infertility, human reproduction.

\section{INTRODUCTION}

Infertility means not being able to procreate. ${ }^{1}$ Assisted Human Reproduction (AHR) consists in a group of treatment techniques used to enable reproduction in people who are infertile or sterile. ${ }^{2}$ Infertility has grown each year. Nowadays, $13-18 \%$ of couples have faced difficulties in getting pregnant. ${ }^{3}$

There are reports of an association between unsanitary chemical and environmental air conditions (e.g., bacteria, dust, particulate matter and volatile compounds) and reducing the rate of success in producing embryos and the occurrence of pregnancy. ${ }^{4-6}$

AHP uses a set of low and high complexity techniques. Intrauterine insemination (IUI) is considered a low complexity technique, while extracorporeal fertilization methods are considered high complexity techniques. This includes classic in vitro fertilization (IVF) and in vitro fertilization through intracytoplasmic sperm injection (ICSI).4,-9

Financial support: None

Conflicts of interest: The authors declare that there is no conflict of interests.

Received: $22 / 02 / 2019$

Accepted: $11 / 03 / 2021$

Study carried out at Human Reproduction Laboratory of the Clinical Hospital of the Federal University of Goias LABREP - HC -UFG.

Copyright Gontijo et al. This is an Open Access article distributed under the terms of the Creative Commons Attribution License, which permits unrestricted use distribution, and reproduction in any medium, provided the original work is properly cited. 
In the last decades, worldwide, women have tended to postpone motherhood, which can be proved by the decrease in the number of pregnancies in women under 40 years old and the increase of this number among women over 40 years old. ${ }^{10}$

In Brazil, there are 106 Human Reproduction labs. From those, nine are located in public institutions and ninetyseven are exclusively private. From the public institutions, six offer the entire treatment free. Other three labs offer free services, however they charge the medication used by the couple. ${ }^{11}$

In the country, until 2006, there was not a legislation that regulated AHP. The human reproduction techniques were regulated by the ethic norms established by the Federal Council of Medicine. It resulted in an exponential increase in multiple pregnancies in Brazil, which is considered a public health issue because of the risks caused to the mothers, the children as well as because of the high costs to the public health system. ${ }^{12}$

On February $17^{\text {th }}, 2006$ it was approved the resolution called RDC n. $33^{13}$. In $4^{\text {th }}$ chapter regulates the minimum infrastructure as well as the environments and equipment characteristics required in Germinal Cells and Tissues Banks (GCTB). Later, this resolution was updated by RDC $\mathrm{n}$. 23 on May $27^{\text {th }}, 2011^{14}$. It was also created the National System of Embryo Production (SisEmbrio ${ }^{\circledR}$ ) that publishes, periodically, information related to embryo production, maintenance, and use in Brazil in order to promote the development of GCTBs' quality indicators. ${ }^{11}$

The Human Reproduction Lab at the Federal University of Goiás School Hospital (LabRep/HC/UFG) in Goiânia, created in 1998, changed its facilities in December, 2013 and went through a readaptation process, changing from a conventional to an ISO 5/7 laboratory.

The ISO 5/7 lab has a climatization system that keeps positive pressure in adjacent environments; temperature control conditions between $23^{\circ} \mathrm{C}$ to $27^{\circ} \mathrm{C}$; relative air humidity between $40 \%$ and $70 \%$; total air minimum flow on $\left.45\left(\mathrm{~m}^{3} / \mathrm{h}\right) / \mathrm{m}^{2}\right)$; exterior air minimum flow on $15\left(\mathrm{~m}^{3} / \mathrm{h}\right) \mathrm{m}^{2}$ and minimum filtering in filters insufflated with $\mathrm{G} 3$ (coarse filter) and F8 filters (fine filters capable of trapping particles of $0.4 \mu \mathrm{m}$ ).,14,15

Regarding the living embryos manipulation room, classified as ISO Class 5, it has a biological security cabinet Class 2, Type $\mathrm{A}$ and an unidirectional flow module. ${ }^{9,11,16}$

This paper aims to verify if the success of fertilization and reproduction in the iso 5/7 laboratory are different when compared to a conventional laboratory?

\section{METHOD}

This control case study was developed at the LabRep/HC/UFG, located in Goiânia, Goiás, Brazil. It uses indirect observation as research technique in order to analyze the records of women attended at the laboratory.

It descriptively evaluates embryo culture plates contamination after they were transferred, based on the possibilities of those being disposed.

The study was submitted to the Federal University of Goiás School Hospital's (HC/UFG) Research Ethics Committee. It was approved under the protocol number 768619.

It was used information from the records of 87 women attended at the conventional laboratory in 2013 and 191 women attended at the ISO 5/7 laboratory in 2014. Together, the research used information of 278 women.

The study was developed between January 2013 and December 2014 and it was divided in two stages:

The data collection was done from January to December 2013 at the conventional lab (period that the LabRep developed its functions in the old facilities) and from January to December 2014 at the ISO 5/7 lab (period that the LabRep made structural adjustments).

In the first stage, although the lab was already working with laminar flow hood, it still did not have controlled temperature conditions as well as air humidity, minimum airflow and minimum filtration with activated carbon filters control. In the second phase, the lab was already located in its new facilities and it met the 2011 RDC $23^{14}$ requirements, which enabled it to be classified as ISO 5/7.

The samples were classified according to age, body mass index, estradiol concentration, stimulating follicle hormone, prolactin, luteinizing hormone, sperm concentrations above 15 million per $\mathrm{ml}$, the total sperm motility $\geq 40$, infertility time, maternal infection and sperm contamination.

The classification through sperm concentration above 15 million per $\mathrm{ml}$ as well as through the total sperm number above 39 million and according to its total motility, at least half of the sperms need to show linear progression, with a motility level above $40 \%$. This index was chosen according to the 2010 World Health Organization recommendation. ${ }^{1}$

The analyses excluded 33 cases from the ISO 5/7 lab because their sperm concentration was under 15 million; 10 cases that presented motility under 40\%; 14 cases that the sperm was contaminated; 50 cases that presented maternal infection; 15 cases that showed anormalities in their estradiol, FSH, prolactin and LH concentration level; and 12 cases with age changes, BMI or infertility time. It was then, left 57 human fertilization treatment cycles to be analyzed. 
From the conventional lab, the analysis excluded seven cases that the after-trained sperm concentration was under 15 million; two cases that presented motility under 40\%; three cases that the sperm was contaminated; 27 cases that showed maternal infection; four cases that had variations in their estradiol, FSH, prolactin and LH concentration level; and four cases with age changes, BMI or infertility time. It was used 47 human fertilization treatment cycles.

The variables analyzed were: procedure type performed; the number of formed embryos; successful pregnancy by types of classified embryos; embryo formation; BHCG result (pregnancy result) and embryo quality.

It was developed an evaluation of the plates' contamination after embryo collection. It was analyzed 55 plates, in which the embryos were cultivated at the ISO 5/7 lab and the results were compared to the culture mediums' contamination at the conventional lab, done by a previous research conducted by Ribeiro ${ }^{7}$, in 2010. In IVF and ICSI, the embryos are formed and collected out of the mother's body, in culture plates. It is possible thanks to the advancement of collection tools, which offer the necessary nutrients to the embryos good development. Those collection plates represent the best place to collect and verify if there is imminent microbiological contamination because all the factors that may cause contamination converge to this cultivation plate, which directly interfere in pregnancy rates.

The embryos were cultivated in HTF (Human Tubal Fluid Irvine Scientific) culture medium or in an Embryo culture medium - Vitro Life (IVF). It was collected materials from 55 embryo plates in 2014, at LabRep according to their disposing availability after they were transferred and then, they were taken to the Ratio Parasite Host Studies Laboratory (LAERPH) at the Federal University of Goiás (UFG) Tropical Pathology and Public Health Institute, where it was investigated if there was contamination and, later it was identified the microorganisms in the samples.

In order to analyze if there was contamination, it was used the culture medium BHI (Brain Heart Infusion), which was prepared according to Kastrop. ${ }^{18}$ The culture medium was replicated in the BHI tubes with broth and incubated for 24 hours at $37^{\circ} \mathrm{C}$ in the LAERPH oven. ${ }^{5}$ The blurred samples would be sub-cultivated in Nutrient Agar (to verify fungi growth), in Sated Agar Manitol to verify Staphylococcus and Bacillus growth and in MacConkey Agar to verify Gram-negative bacteria growth. The isolated samples would be identified through morph types' characterization (blue lactophenol - fungi and Gram stain - bacteria). For gram-positive organisms, it would be performed catalase and coagulase production tests. For gram-negative bacillus, it would be done bacterial metabolic identification biochemical tests. ${ }^{19}$

The data was evaluated in the Epi-Info 3.3.2 ${ }^{\circledR}$ e BioEstat 5.3 ${ }^{\circledR}$ program. It was set up contingency tables and graphs in order to determine the association among the variables. Later, Conventional Lab and ISO 5/7 patients' data was compared through chi-square $(\chi 2)$ test or Fisher's exact test. It was used a $5 \%$ significance level.

This research was limited sample size. It is expected that in a larger temporal analysis, the results could be more robust, reducing the sample bias.

\section{RESULTS}

It was selected 47 women attended at the Human Reproduction Conventional Lab in 2013 and 57 women attended at the Federal University of Goiás School Hospital Human Reproduction Lab new facilities (LABREP-HC-UFG) in 2014, what together corresponds to 104 women. The women reproductive characteristics sample are described on Table 1.

Tabela 1. Reproductive characteristics of women treated at ISO 5/7 laboratory and conventional laboratory Hospital of the Federal University of Goiás in the years 2013 and 2014.

\begin{tabular}{|c|c|c|c|c|}
\hline \multicolumn{2}{|c|}{ Characteristics } & $\begin{array}{c}\text { Conventional Laboratory } \\
\text { (47 women) }\end{array}$ & \multirow{2}{*}{$\begin{array}{c}\text { ISO 5/7 Laboratory } \\
\text { (57 women) }\end{array}$} & $p$ \\
\hline & & & & \\
\hline Age & & 34.034 (IC: 25.00 - 45.00) & 34.921 (IC: 21.00 - 44.00) & 0.81 \\
\hline BMI & & 24.628 (IC: 19.00 - 39.00) & 23.885 (IC: 17.00 - 39.00) & 0.76 \\
\hline Estradiol & & 49.593 (IC: 3.08 - 551.01) & 51.212 (IC: 7.90 - 364.40) & 0.09 \\
\hline LH & & 6.890 (IC: 0.80 - 434.00) & 8.049 (IC: 0.80 - 334.00) & 0.12 \\
\hline FSH & & 8.496 (IC: 3.66 - 82.30) & 6.420 (IC: 3.10 - 20.47) & 0.99 \\
\hline \multicolumn{2}{|l|}{ Prolactin } & 14.950 (IC: $4.48-48.80)$ & 15.370 (IC: 4.30 - 30.94) & 0.07 \\
\hline \multirow{3}{*}{ Infertility time } & $12-3$ years & $18(38.29 \%)$ & $23(40.35 \%)$ & 0.08 \\
\hline & 4-8 years & $19(40.42 \%)$ & $21(36.84 \%)$ & 0.23 \\
\hline & $>9$ years & $10(21.28 \%)$ & $13(22.81 \%)$ & 0.34 \\
\hline
\end{tabular}

IC: confidence interval; BMI: Body mass index; LH: Luteinizing Hormone; FSH: Follicle Stimulating Hormone 
The researched analyzed 104 complete cycles, 47 from the conventional lab in 2013 and 57 from the ISO 5/7 lab in 2014. From the 47 cycles that came from the conventional lab, 20 were evaluated through ICSI, 11 through FIV and 16 through IIU. From the 57 cycles that came from the ISO 5/7 lab, 24 were analyzed through ICSI, 17 through FIV and 16 through IIU.

In regard to the number of formed embryos, through the high complexity techniques ICSI and FIV, it was observed higher success at the ISO $5 / 7$ lab, with $74,1 \%{ }^{20}$ in relationship to the conventional lab that presented $67.8 \%{ }^{2}$ of success (Figure 1 ).

For the classification of embryos, followed by the Depa-Martynow et al. ${ }^{21}$, where embryos were classified according to their fragmentation: The A (embryos without fragmentation and symmetric), B (Asymmetric embryos with up to $25 \%$ fragmentation), C (embryos having from 25 to $50 \%$ fragmentation) and D (embryos with $50 \%$ or more of fragmentation). The worse the morphology, the lower the chances of implantation and pregnancy. Properly fertilized oocytes are transferred individually to drop with mineral oil, $0.025 \mathrm{ml}$ medium cleavage. As a criterion used to assess embryo quality are considered the following parameters: presence of anucleated cytoplasmic fragments and the relative size of the blastomeres.

$\begin{array}{llllllll}\text { OR } & 1.30 & \text { IC } & 0.47-3.61 & \chi^{2} & 0.25 & P & 0.81\end{array}$

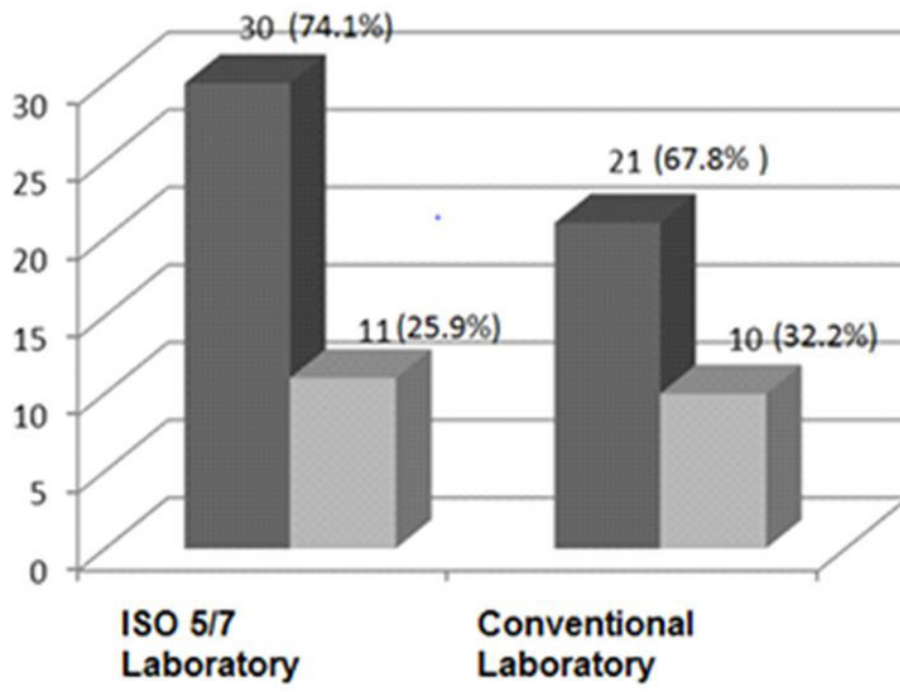

Formed embryo

II Not embryo formed

Figure 1. Comparison between embryo formation in a ISO 5/7 lab and a conventional lab in 2013 and 2014 in Goiânia, Goiás, Brazil.

With reference to embryo quality, it was observed at the ISO 5/7 lab that $73.3 \%$ were classified as A, $23.3 \%$ as B and $3.3 \%$ as $C$ and no embryo was classified as D. Meanwhile, at the conventional lab, $71.4 \%$ were classified as A, $19.0 \%$ as B, 4.8\% classified as D (Figure 2).

It was observed at the ISO $5 / 7$ lab that $96,6 \%(73,3 \% \mathrm{~A}$ and $23,3 \% \mathrm{~B})$ of the embryos generated were classified as $\mathrm{A}$ or B, which means, they were good. At the conventional lab, 90,4\% (71,4\% A and 19,0\% B) were A or B (Figure 3).

Comparing pregnancy success, it was detected that at the ISO 5/7 lab the pregnancy index was $22,8 \%$. In the meantime, at the conventional lab it was $36.2 \%$ (Figure 4).

It was evaluated embryo culture medium microbiological contamination after the embryos were transferred into the women's uterus.

No sample showed microbiological contamination and, consequently, there was no interference in the human reproduction treatment results and success. 


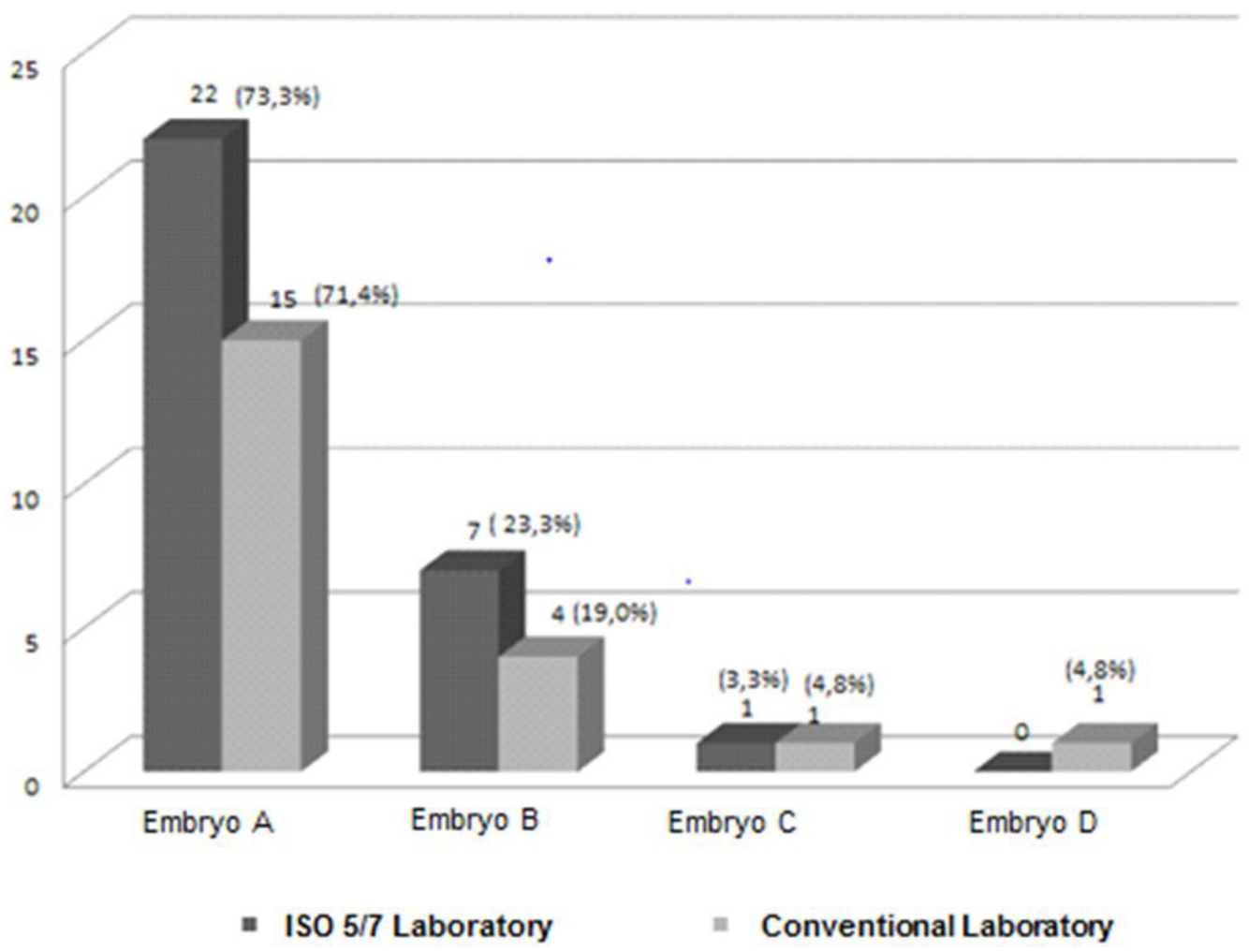

Figure 2. Patients distribution according to embryo frequency classes A, B, C and D at the ISO 5/7 Lab and at the conventional lab in 2013 and 2014, in Goiânia, Goiás, Brazil.
OR
0,8906
IC
$0,27-2,89$
$\chi^{2} \quad 0,037$
$P \quad 0,85$

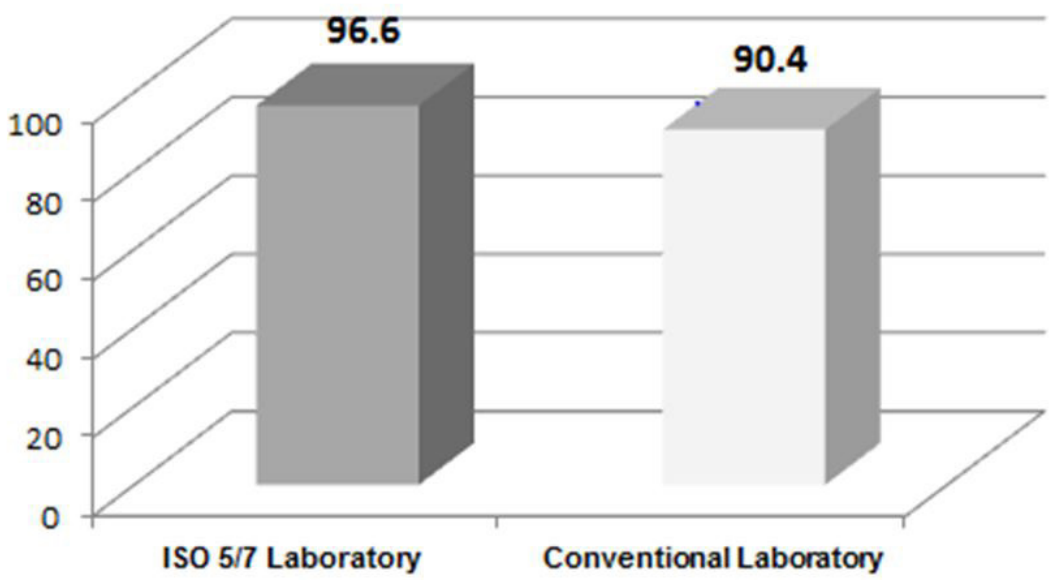

Figure 3. Patients distribution according to embryos A or B and C or D percentage between the ISO 5/7 and the conventional lab in 2013 and 2014, in Goiânia, Goiás, Brazil. 

OR: 1,9197 ;
IC: $0,81-4,52$;
p: 0,13 ;
$\chi^{2} 2,24$

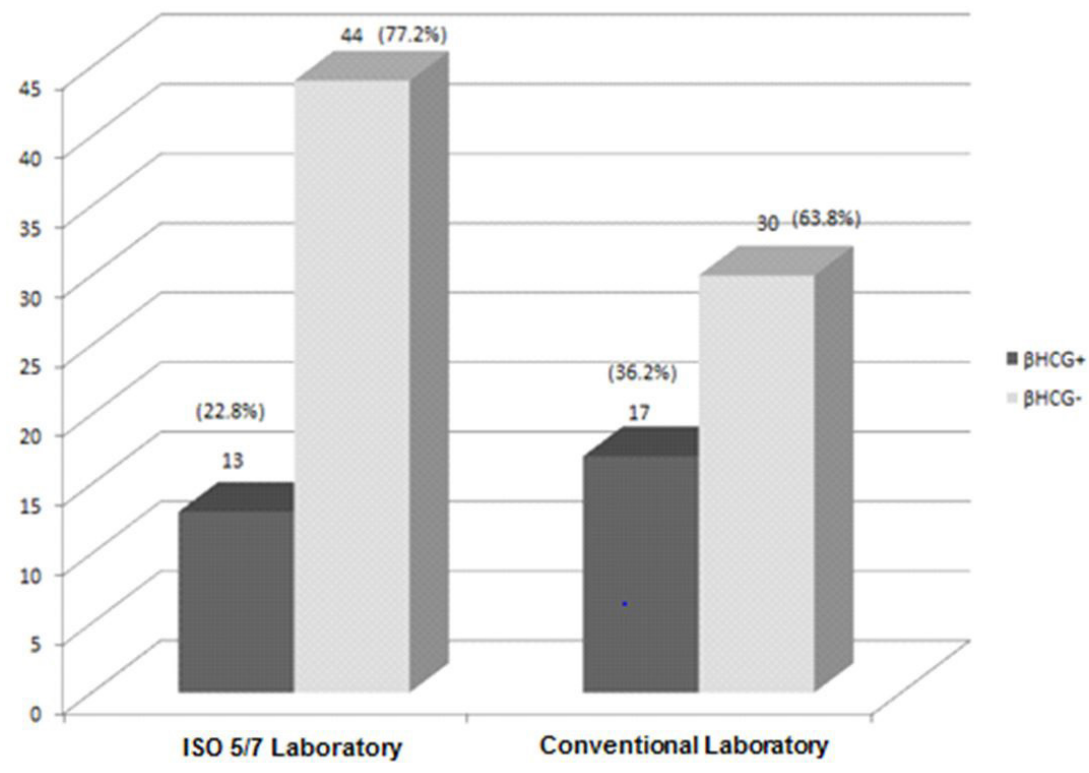

Figure 4. Comparison between pregnancy success at the ISO 5/7 laboratory and at the conventional lab in 2013 and 2014 , Goiânia, Goiás, Brazil.

\section{DISCUSSION}

In AHR labs, quality control is very relevant in order to achieve a successful treatment. The correct execution of techniques directly influences the results. A high level of hygiene, cleaning and material disposal must be observed to prevent embryos and culture plates' equipment infection. Fungicides should be added to the plates, in which the embryos are grown, as it increases microorganisms' resistance. Each step during the manipulation of gametes and embryos should be performed using precisely filed aseptic techniques.

In 2014, the ISO 5/7 lab achieved 74,1\% of embryo formation. The conventional lab (data from 2013) achieved 67,8\%, which is not considered a significant difference. On the other hand, in regard to embryo quality (embryos A or B), it was found $96,6 \%$ of those embryos at the ISO 5/7 lab, while the conventional lab presented $90,4 \%$. The rates were inferior; however there weren't significant statistic difference.

Khoudja and his colleagues evaluated the blastocyst production rate before and after the installation of a new air filtration system. He noticed that there was a significant increase of $38,1 \%$ to $51,1 \%$ in the blastocyst production rate after the new air filtration system was installed. ${ }^{6}$

An observational study in 468 ICSI cycles compared embryo production in two labs. The first lab's facilities had a clean room with an air filtration system in the culture room. The second one had conventional facilities and its air filtration system was independent. The lab that had clean room achieved better results. It produced higher quality embryos when compared to the conventional lab. ${ }^{22}$

Munch et al. ${ }^{6}$ developed an observational research and compared 524 FIV fresh cycles and 156 cryopreserved cycles in the same lab in two different periods of time. In the first period, the lab had a carbon filtration system and in the second one there wasn't a filtration system. The embryo cleavage rates decreased when the filtration system was removed, but it increased when the system with carbon filtration was reintroduced.

A research conducted by Ziebe and his colleagues verified that embryo rates type A implemented were $28 \%$, while type D was only $5 \%{ }^{23}$

Giorgetti et al. ${ }^{24}$ studied more than 900 FIV cycles. The results show a lower pregnancy rate when it was implanted a type D embryo, 4,5\%. Staessen et al. ${ }^{25}$ achieve only one pregnancy and transferred 68 embryos that were highly fragmented. In another publication, Shulman et al. ${ }^{25}$., did not achieve any pregnancy. ${ }^{26}$ Although embryos morphologically classified as $\mathrm{D}$ are able to start a pregnancy, some researchers believe that the fetus does not have high chances to be born. For example, Giorgetti et al. ${ }^{24}$ achieved only 3,8\% of birth. Ebner ${ }^{27}$ and his colleagues reported that children born with fetal 
malformation rate with embryos classified as $C$ and $D$ are respectively 13.3 and $36.4 \%$. It can be possibly explained by the higher degree of apoptosis, chromosomal disorder 32 and regulatory proteins loss ${ }^{28-30}$.

In Donadio et al..$^{31}$ research it was found $42 \%$ of pregnancy with embryos morphologically classified as $\mathrm{A}, 38 \%$ of pregnancy with embryos type B, $24 \%$ of pregnancy with group C embryos and $11 \%$ of pregnancy in women that received embryos morphologically classified as D. Showing indices similar to those found in other studies, showing the tiny, but still present evolutionary capacity of these embryos, even with many fragmentations in their morphology.

In our research the results were similar to those found by Ziebe et al. ${ }^{23}$., Giorgett et al. ${ }^{24}$ and Donadio et al. ${ }^{31}$, in which were noticed higher success in production and embryo quality at the ISO 5/7 lab, where it was implemented a filtering system. $26,31,32$

In regard to pregnancy success ( $\beta \mathrm{HCG}+$ ) in both labs, it was noticed that the difference between them is statistically insignificant. Nevertheless, the data is different that we previously expected because the new facilities completely meet the criteria established by the RDC $n .23$ resolution, from May $27^{\text {th }}, 2011$. Because of that, we expected that the results were more promising when compared to the old facilities. This greatly surprising result requires a thorough investigation of all aspects, clinical, structural, medical, and infectious as well as the partner involved in the process. ${ }^{13}$

A research developed during 12 months found no increase in documentary pregnancy rates after the implementation of a modern filtration system. According to the researchers, even with the filtering system, the air quality was still poor. In addition, the hot and humidweather in Cantão (China) could have influenced the filters saturation before the expected time, which prevented volatile organic compounds to be removed and decreased the installed air system effectiveness. ${ }^{33}$

Cohen et al. ${ }^{20}$ observed that pregnancy rates in his lab decreased when one of his neighbors renovated his apartment. The neighbor replaced the floor using a large amount of adhesive, which produced a considerable volume of volatile organic compounds. It contaminated his laboratory and decreased pregnancy rates.

Boone et al. ${ }^{33}$ found a similar result. His assisted human reproduction lab at the Greenville Hospital, located in South Carolina, US, went through an expansion process. During the renovation, he noticed that it triggered the production of detectable odors in his lab. It was observed an increase in the levels of dust and other particles associated with equipment installation as well as odors from paint and glue tiles. Meanwhile, the clinical pregnancy rate decreased and the in vitro fertilization processes success decreased 35\% (25 of 71) in 1993 and to 16\% (11 of 68) in 1994. Thus, it was demonstrated, for the first time, that bad air quality might cause low embryo development. Once the air was cleaned and the odors reduced, they observed that, in the following years, the pregnancy rate increased. The rates gradually increased in 1995 (20\%) after they installed a clean room and, later, it drastically grew in 1996 and 1997 (32\% and 59\% respectively). ${ }^{25}$

Microbiological contamination in embryo culture medium after cultivation and after it was transferred to women's uterus was also evaluated. The contamination exam that analyzed the existence of microorganisms was negative in all the samples, what shows that there was no interference between the results and the success of the human reproduction treatment.

Knowing about the possible risk of contamination either from the gametes or from the internal air, shows that it is necessary to track the microbiological contamination in the human reproduction laboratory in order to investigate the association between microbiological contamination and success in human reproduction. ${ }^{4}$

At the old LabRep-HC-UFG facilities, Foizer developed a post embryonic incubation microbiological analysis in the embryo culture mediums and found 6 contaminated plates in 125 samples (4,8\%). The microorganisms found were Escherichia coli (50\%), Klebsiella sp (16,6\%), Pseudomonas sp (16,6\%), Levedura (16,6\%). Escherichia coli was the bacteria with higher incidence, found in three of the samples. Resistant gram-negative rods were found, although the culture mediums show the use of antibiotics such as Penicillin G (IVF) or Gentamicin (HTF).

The fact that the current lab's culture mediums were not contaminated shows that nowadays there is a more rigorous embryo manipulation and the environment with clean and positive pressure air has played its role of maintaining the embryos free of microbiological interference.

\section{CONCLUSION}

The LabRep/HC/UFG adequation to the 2011 RDC n. 23 resolution was a great evolution to the treatment in the Centerwest region of the country. However, in general, in regard to the embryo formation success as well as the embryo quality and fertilization success, the results found were similar in the two labs.

Concerning microbiological contamination, the culture mediums after collection were not contaminated, what shows that changes in the lab infrastructure reflected positively in preventing medium contamination. Notwithstanding, it did not reflect in the treatment rate success.

This study did not deplete the discussion about how the environment can interfere on AHR success at the LapRepHC-UFG. We suggest a follow up study for a longer period of time, once the success rate of the assisted reproduction techniques may gradually improve.

The authors declare that there is no conflict of interests. 


\section{REFERENCES}

1. World Health Organization. Global status report on non communicable diseases 2010 [Internet]. Geneva: WHO; 2010 [cited 2019 Feb 22]. Available from: http://www.who.int/nmh/publications/ncd_report_full_en.pdf

2. European Society of Human Genetics. Assisted reproductive technology in Europe. In: Proceedings of the 23 rd Annual Meeting of the European Society of Human Reproduction and Embriology - ESHRE [Internet]. Vienna: European Society of Human Genetics; 2007 [cited 2019 Feb 22]. Available from: https://www.eshg.org/94.0.html

3. Moraes PF, Gigante LP, Ferrari AN, Mattos ALG. Evolução de casais inférteis por um período de até 10 anos. Revista AMRIGS. 2015;48(4):230-4.

4. Gontijo ÉEL, Approbato MS. Relationship between biochemical, environmental, and microbiological changes with the success rate of fertilization techniques. JBRA Assist Reprod. 2013;17(6):357-8. http://dx.doi.org/10.5935/1518-0557.20130081.

5. Foizer BRR, da Silva KR, Vieira JDG, do Amaral WN. Contaminação microbiológica em laboratório de reprodução humana e suas implicações no sucesso da reprodução assistida. Reprodução \& Climatério. 2014;29(2):66-70. http://dx.doi.org/10.1016/j. recli.2014.08.005.

6. Munch EM, Sparks A, Duran H, Van Voorhis B. Lack of carbon air filtration impacts early embryo development. J Assist Reprod Genet. 2015;32(7):1009-17. http://dx.doi.org/10.1007/s10815-015-0495-1. PMid:26003657.

7. FOIZER BRR. Investigação bacteriológica e Micológica em placas de cultivo de embriões em laboratórios de reprodução humana Goiânia. Goiânia: Universidade Federal de Goiás; 2010.

8. Mendes AIG, Silva MSE, Do Amaral WN, De Castro EC. Confiabilidade da contagem de folículos antrais com o uso de ultrassom bidimensional e tridimensional: uma revisão sistemática. Reprodução \& Climatério. 2014;29(2):48-53. http://dx.doi.org/10.1016/j. recli.2014.08.001.

9. Bento F, Esteves S, Agarwal A. Quality Management in ART Clinics [Internet]. 2013. Available from: http://link.springer.com/ content/pdf/10.1007/978-1-4419-7139-5.pdf

10. Klipstein S, Regan M, Ryley D, Goldman M, Alper M, Reindollar R. One last chance for pregnancy: a review of 2,705 in vitro fertilization cycles initiated in women age 40 years and above. Fertil Steril. 2005;84(2):435-45. http://dx.doi.org/10.1016/j. fertnstert.2005.02.020. PMid:16084887.

11. Brasil. Agência Nacional de Vigilância Sanitária. $8^{\circ}$ Relatório do Sistema Nacional de Produção de Embriões Agência [Internet]. Brasília: ANVISA; 2015 [cited 2019 Feb 22]. p. 1-27. Available from: http://portal.anvisa.gov.br/wps/wcm/connect/9cddb8004840 da35a438a5bdc15bfe28/sisembrio8.pdf?MOD=AJPERES

12. Freitas M, Siqueira AA, Segre CA. Avanços em reprodução assistida. Revista Brasileira de Desenvolv Hum. 2008;18(1):93-7.

13. Brasil. Agência Nacional de Vigilância Sanitária. Resolução RDC n³3, de 17 de fevereiro de 2006. Aprova o Regulamento técnico para o funcionamento dos bancos de células e tecidos germinativos [Internet]. Diário da República Federativa do Brasil; Brasília; 2006 [cited 2019 Feb 22]. Available from: http://adcon.rn.gov.br/ACERVO/Suvisa/doc/DOC000000000025025.PDF

14. Brasil. Ministério da Saúde. Agência Nacional de Vigilância Sanitária. Resolução- RDC n²3, de 27 de maio de 2011 [Internet]. Diário da República Federativa do Brasil; Brasília; 2011 [cited 2019 Feb 22]. Available from: http://portal.anvisa.gov.br/wps/wcm/ connect/d3f7c4804986e29a8e51ff4ed75891ae/RDC_23_2011.pdf?MOD=AJPERES

15. Freitas M, Siqueira AA, Segre CAM. Avanços em Reprodução Assistida Advances. Revista Brasileira de Crescimento e Desenvolvimento Humano. 2015;7(11):956-63.

16. Esteves S C. Sala limpa Classe 100 / ISO 5: Condição sine qua non nos laboratórios de reprodução assistida ? Arquivos H ELLIS. 2007;3(4):1-15.

17. Foizer BRR, do Amaral WN, Sadoyama G. Investigação bacteriológica e micológica de placas de cultivo de embriões em laboratório de reprodução humana. Reprodução \& Climatério. 2010;26(1):12-8.

18. Kastrop PM, de Graaf-Miltenburg LA, Gutknecht DR, Weima SM. Microbial contamination of embrio cultures in an ART laboratory: sourses and management. Hum Reprod. 2007;22(8):2243-8. http://dx.doi.org/10.1093/humrep/dem165. PMid:17584750.

19. Koneman E. Diagnóstico microbiológico: texto e atlas colorido. 6. ed. Rio de Janeiro: Guanabara Koogan; 2008.

20. Cohen J, Gilligan A, Esposito W, Schimmel T, Dale B. Ambient air and its potential effects on conception in vitro. Hum Reprod. 1997;121(8):1742-9. http://dx.doi.org/10.1093/humrep/12.8.1742. PMid:9308805.

21. Depa-Martynow M, Jedrzejczak P, Pawelczyk L. Pronuclear scoring as a predictor of embryo quality in in vitro fertilization program. Folia Histochem Cytobiol. 2007;45(Suppl 1):S85-9. PMid:18292842.

22. Esteves SC, Bento FC. Air quality control in the ART laboratory is a major determinant of IVF success. Asian J Androl. 2015;18(4):596-9. PMid:26585700.

23. Munch EM, Sparks A, Duran H, Van Voorhis B. Lack of carbon air filtration impacts early embryo development. J Assist Reprod Genet. 2015;32(7):1009-17. http://dx.doi.org/10.1007/s10815-015-0495-1. PMid:26003657.

24. Giorgetti C, Terriou P, Auquier P, Hans E, Spach JL, Salzmann J, et al. Embryo score to predict implantation after in-vitro fertilization: based on 957 single embryo transfers. Hum Reprod. 1995;10(9):2427-31. http://dx.doi.org/10.1093/oxfordjournals.humrep. a136312. PMid:8530679.

25. Ziebe S, Petersen K, Lindenberg S, Andersen A, Gabrielsen A, Andersen A. Embryo morphology or cleavage stage: how to select the best embryos for transfer after in-vitro fertilization. 1997;12(7):. Hum Reprod. 1997;12(7):1545-59. 
26. Shulman A, Ben-Nun I, Ghetler Y, Kaneti H, Shilon M, Beyth Y. Relationship between embryo morphology and implantation rate after in vitro fertilization treatment in conception cycles. Fertility and sterility [Internet]. 1993 Jul;60(1):123-6. Available from: http://www.ncbi.nlm.nih.gov/pubmed/8513927.

27. Ebner T, Yaman C, Moser M, Sommergruber M, Polz W, Tews G. Embryo fragmentation in vitro and its impact on treatment and pregnancy outcome. Fertil Steril. 2001;76(2):281-95.

28. Khoudja RY, Xu Y, Li T, Zhou C. Better IVF outcomes following improvements in laboratory air quality. J Assist Reprod Genet. 2013;30(1):69-76. http://dx.doi.org/10.1007/s10815-012-9900-1. PMid:23242648.

29. Esteves SC, Bento FC. Implementation of air quality control in reproductive laboratories in full compliance with the brazilian cells and germinative tissue directive. Reprod Biomed Online. 2013;26(1):9-21. http://dx.doi.org/10.1016/j.rbmo.2012.10.010. PMid:23177417.

30. Khoudja RY, Xu Y, Li T, Zhou C, Better IVF outcomes following improvements in laboratory air quality. J Assist Reprod Genet. 2013;30(1):69-76. http://dx.doi.org/10.1007/s10815-012-9900-1. PMid:23242648.

31. Donadio NF, Donadio N, Celestino CO. Caracterização da inviabilidade evolutiva de embriões visando doações para pesquisas de células-tronco. Rev bras ginecol obstet [Internet]. 2005;27(11):665-71. Available from: http://www.scielo.br/pdf/rbgo/v27n11/28708 pdf.

32. Meyer A, Sarcinelli PN, Moreira JC. Estarão alguns grupos populacionais brasileiros sujeitos à ação de disruptores endócrinos? Cad Saude Publica. 1999;15(4):845-50. http://dx.doi.org/10.1590/S0102-311X1999000400018. PMid:10633206.

33. Boone W, Johnson J, Locke A, Crane M, Price T. Control of air quality in an assisted reproductive technology laboratory. Fertility and Sterility [Internet]. 1994;71(1):1-12. Available from: http://www.ncbi.nlm.nih.gov/pubmed/9935133

\author{
*Correspondence \\ Érica Eugênio Lourenço Gontijo \\ University of Gurupi \\ Av. Rio de Janeiro $n^{\circ} 1585$, Centro \\ Gurupi - TO \\ Phone: (63) 98436-6288 \\ E-mail: ericagontijo1@yahoo.com.br
}

\title{
Author information
}

$1 \mathrm{PhD}$ in Health Sciences from the Federal University of Goias. Professor at the University of Gurupi, Tocantins. Author for correspondence: Av. Rio de Janeiro n 1585, Centro, Gurupi - TO. Phone: (63) 98436-6288. E-mail: ericagontijo1@yahoo.com.br

2 PhD in Tropical Medicine from the Federal University of Goias Phone: (63) 98469-4340. E-mail: gontijobio@yahoo.com.br 3 PhD in parasitology from the Federal University of Minas Gerais. Phone: (62) 3209-6109. E-mail: amaria.ana@gmail.com 4 PhD in Tropical Medicine from the Federal University of Goias Phone: (62) 3209-6109. E-mail: hanstter.bio@hotmail.com 5 PhD in Tocoginecology from the University of São Paulo. Full professor at the Federal University of Goias, Brazil. Phone: (62) 99979-2255. E-mail: approbato.m@gmail.com

\section{Author contributions}

Érica Eugênio Lourenço Gontijo - Project construction, data collection, data analysis and article writing

Marcos Gontijo da Silva - Data analysis

Ana Maria de Castro - Execution of microbiological analyzes

Hanstter Hallison Alves Rezende - Execution of microbiological analyzes

Mário Silva Approbato - Work orientation and data analysis

$\begin{array}{ll}\text { ABBREVIATIONS AND SYMBOLS } \\ \text { AHR } & \text { Assisted Human Reproduction } \\ \text { BMI } & \text { Body Mass Index } \\ \text { FSH } & \text { Follicle-Stimulating Hormone } \\ \text { GCTB } & \text { Germinal Cells and Tissues Banks } \\ \text { HC/UFG } & \text { Federal University of Goiás School Hospital's } \\ \text { HTF } & \text { Human Tubal Fluid } \\ \text { ICSI } & \text { Intracytoplasmic Sperm Injection } \\ \text { IUI } & \text { Intrauterine Insemination } \\ \text { IVF } & \text { In Vitro Fertilization } \\ \text { LAERPH } & \text { Ratio Parasite Host Studies Laboratory } \\ \text { LH } & \text { Luteinizing Hormone }\end{array}$

